V. A preliminary revision of the Forficulidæ (sensu stricto) and of the Chelisochidæ, families of the Dermatoptera. By Malcolm Burr, B.A., F.E.S., F.Z.S., F.L.S., F.G.S.

[Read March 6th, 1907.]

Plate IV.

A Careful study of the genus Opisthocosmia, Dohrn., as understood by de Bormans, has revealed a mass of incongruities and a number of new characters. A cursory examination has shown that very dissimilar species were ranged together, and that it was necessary to define the genus with greater precision and to reject many diverse forms which had been hitherto included. The development of this process soon showed that many allied genera were involved, until it became necessary to recast entirely that group of genera in which the second tarsal segment is cordiform. I regard this as a highly significant character (differing in this point diametrically from Dr. Verhoeff), which neatly defines the Forficulidx, a name which I restrict to those earwigs possessing this character, regarding the group as a family of the order Dermatoptera.

The task of revising the Augæan stable will take so long a time, and so many years must elapse before the appearance of the final monograph, that $I$ have resolved to publish this preliminary report as the result of a study of these genera. Dr. Verhoeff included them in his first "Aufsatz," but lack of material rendered his work in this respect incomplete.

Thus it will be seen that my use of the name Forficulida does not coincide exactly with that of Verhoeff, for that author rejected the shape of the second tarsal segment as a valuable character; he included Spongiphora and Nesogaster and Sparatta, with their allies, which appears to me to be an eminently unnatural and artificial arrangement. The German author distinguishes the Forficulidx from the Labidurida by the single development of the genitalia, which we do not employ, for reasons stated elsewhere, and by the presence of the stink-glands on the sides of the abdomen; he excludes Chelidura and its allies on account of their entire winglessness, but the lobed second tarsal segment appears to be such a strong

TRANS. ENT. SOC. LOND. 1907.-PART I.

(JUNE) 
character, that I prefer to employ it to define this family; it does not seem likely that the shape of this segment has any direct influence upon the insects' life or habits; it is probably a relic of some ancient specialisation, and therefore unlikely to be so subject to fluctuation as an organ in activity, the lateral stink-glands for instance, which vary with the age of the individual. It is also by the rudimentary remains of once active organs that we may best hope to trace the natural affinities of the different species, which is the ultimate aim of all classifications.

Dr. Verhoeff's work is very valuable, and it is a pity that he marred it by such faults as the incorrect use of the name Sphingolabis, and the separation of Cosmiella based on the absence of wings, a character upon which Orthopterists and Dermapterists are agreed it is useless to found even a species.

The synoptical tables for the determination of species must not be regarded with too critical an eye; they are offered with no attempts at dogmatism, but only as helpnotes for entomologists who wish to determine earwigs.

It will be observed that several new characters are used. Greater stress than previously is here laid upon the form and relative sizes of the first four or five segments of the antennæ, and also on the form of the pronotum and legs. Verhoeff used the carina of the elytra in a few instances; in certain genera the slight fold, which roughly divides the elytra into a large dorsal and a small and narrow costal or lateral portion, is emphasised and strengthened into a sharp ridge or keel, which in some cases extends the whole length of the elytron, and in others dies out half-way down. More attention is also paid to the shape of the abdomen.

The chief point which leads me to hope that this attempt at a new classification will be found to approach more nearly to the true natural arrangement is the fact that the groups are now divided more or less according to their geographical distribution. Formerly, Opisthocosmia was regarded as a characteristically Asiatic genus, until $O$ americana and 0 . amazonensis were described from South America; conversely, the discovery of Ancistrogaster javana robbed that genus, in its old sense, of its peculiarity to America. But a glance at the tables proposed in the following pages will show that true Opisthocosmia, as now defined, is confined to the tropical regions of the Old World, 
and all the Ancistrogastrinx, sensu stricto, occur only in tropical America.

But it takes more than a few years to mature an attempt at originality, and doubtless in the course of time, as our knowledge progresses, this proposed arrangement will be profoundly modified. Still, I do think it is worth while offering this system, as an improvement upon the old arrangement, when all kinds of earwigs from various regions were thrown together in a heterogeneous mass under the hitherto very elastic names of Opisthocosmia and Apterygida. De Bormans included no less than twentyseven species in the latter genus, and various recently described forms have been included since. I now confine it to the single typical $A$. media. The other names included by de Bormans under the heading Apterygida, will be found scattered in numerous other genera, sub-families, and even families. Some will be found eventually placed near Labidura, others near Labia; others again near Spongiphora, and for others entirely new genera and sub-families must be formed.

I hope that this attempt at revision approaches more nearly to the natural classification; it claims at least the merit of originality.

\section{FORFICULID $\nRightarrow$.}

TABLE OF THE SUB-FAMILIES OF THE FORFICULIDAE.

1. Corpus apterum.

1.1. Elytra libera, perfecte explicata, vel rudimentaria; alæ perfecte explicatæ vel abortivæ.

2. Antennæ segmentis 4 et 5 subconicis

2.2. Antennæ segmentis 4 et 5 cylindricis.

3. Antennæ segmentis gradatim elongatis, 4 quam 3 longius, 5 quam 4 etc.

4. Antennæ segmento primo valido, tricarinato . . . . . .

1. Chelidurina.

4.4. Antennæ segmento primo cylindrico.

5. Pedes breves; pygidium breve, latum, transversum . . . .

2. Anechurinæ.

3. Eudohrninate.

4. Diaperasticinas. 
5.5. Pedes longi; pygidium brevissimum, angustum, obtusum, vel nullum.

6. Abdomen apice attenuatum ; segmentum ultimum dorsale valde declive, attenuatum .

6.6. Abdomen apice vix atten-

5. Opisthocosmina. uatum, segmentum ultimum dorsale depressum, breve, latum, rectangulare, transversum . . .

3.3. Antennæ segmentis 3, 4 and 5 6. Ancistrogastrinæ. inæqualibus.

4. Antennæ segmento 4 quam 3 muito brevius, quam 5 dimidio brevius ; (elytra haud carinata)

4.4. Antennæ segmentis 4 and 3 subæquantibus.

5. Elytra carinata.

6. Elytra per dimidium longitudinis carinata . . . .

6.6. Elytra per totam longitudinem carinata . . . .

7. Forficulinæ.

8. Skendylinæ.

9. NEOLOBOPHORINÆ.

5.5. Elytra haud carinata.

6. Abdomen convexum, cylindricum . . . . . 10. Eparchinæ.

6.6. Abdomen plus minus depressum . . . . 11. Doratine.

Sub-family 1.-CHELIDURIN E.

This sub-family has been rearranged by Verhoeff (Zool. Anzeiger, 1902, p. 187). He removed those species with free but rudimentary elytra to the Anechurinx, under the name of Pseudochelidura, and the remainder he subdivided into three genera based on the shape of the abdomen, namely, Chelidura, Mesochelidura and Chelidurella. Nothing has been added to our knowledge of these genera since that date.

\section{Sub-family 2.-ANECHURIN $E$.}

This group was first separated from the other genera of the Forficulidx, sensu stricto, by Verhoeff, but he discrimniated Allodahlia, for which, quite unnecessarily, he erected 
a distinct sub-family; the characters, however, are marked enough to separate a genus.

The Anechurinx are distinguished by the sub-conical 4th and 5th segments of the antennæ, by the often short and broad pronotum, by the broad and flattened elytra, often with sharp humeral carinæ, by often short, and broad, pygidium, and by long and slender legs; also by the branches of the forceps in the male, which are remote at the base, not depressed nor thickened; they are often bent and bowed upwards and downwards, in and out, in a very characteristic manner. The last dorsal segment of the abdomen is shorter and narrower than the preceding segments, which are usually somewhat dilated; the last segment is also short, and often armed with tubercles pointing in different directions.

The members of this sub-family usually occur in mountainous countries; with the exception of $A$. elongata, a little known species recorded from Cuba, they appear to be confined to the Old World.

\section{TABLE OF GENERA.}

1. Abdomen depressum, fortius dilatatum.

2. Pedes longi, graciles; abdomen apice latissimum, segmento ultimo brevissimo, transversum.

3. Elytra carinata, rugosa . . . 1. Allodahlia, Verhoeff.

3.3. Elytra haud carinata, lævia.

4. Elytra et alæ perfecte explicatæ . . . . . . .

4.4. Elytra brevia; alæ nullæ.

2.2. Pedes breves, crassi ; abdomen

2. Anechura, Scudd.

3. Pseudochelidura, Verhoeff.

medio dilatatum, apice fortiter attenuatum; segmento ultimo angusto

\section{Chamaipetes, $n$.}

1.1. Abdomen convexum, subcylindricum ; (femora robusta) . . 5. Timomenus, $n$.

\section{Genus Chamaipetes, ** nov. gen.}

Corpus robustum, depressum; abdomen medio dilatatum, apice fortiter attenuatum; antennæ segmentis validis, tertio quartoque subæquantibus, subcylindricis, ceteris longioribus, conicis ; pronotum

* Gr. $\chi a \mu a \iota \pi \epsilon \tau \dot{\eta} s=$ creeping. 
margine antico recto, postico rotundato, prozona elevata, metazona depressa ; elytra alæque perfecte explicatæ ; pedes breves, sat validi, femoribus sat incrassatis; segmentum anale breve, transversum; pygidium haud perspicuum.

Type.-Anechura hermes, Burr, Ann. Mag. N. H. ser. 7, vol. vi, p. 99, Pl. IV, fig. 1, 1 $a$. (1900.) (Sarawak.)

The female is unknown.

I have erected this genus for the reception of the single species referred to which is allied to T. bicuspis, Stål, and its neighbours, but differs in the strongly depressed and dilated abdomen.

\section{Genus Timomenus,* nov. gen.}

Statura minus gracili; antennæ 12-segmentatæ, segmentis crassioribus, minus elongatis ; caput læve, margine postico recto ; pronotum quam caput æque latum, sublatius quam longius, margine antico recto, postico rotundato, lateribus, subconvexis; prozona tumida, distincta, a metazona plana sejuncta: elytra ampla, lævia, carinula humerali brevissima, apice truncata vel emarginata; alæ longæ; pedes minus graciles, femoribus anticis incrassatis; abdomen medio dilatatum, plicis distinctis ; lateribus acute recurvis, in modum generis Ancistrogastris, sed haud mucronibus deplanatis armatis ; segmentum ultimum dorsale of angustatum, læve, medio bituberculatum; forcipis bracchia sat valida, margine interno dentibus obsoletis.

This genus will include a few medium-sized, stout, Asiatic earwigs, with thickened femora, strong forceps, and slightly dilated subcylindrical abdomen.

Type-_Opisthocosmia oannes, Burr, Ann. Mag. N.H. ser. 7, vol. vi, p. 85. (1900.) (India.)

This genus will also include the following:-

Opisthocosmia komarowi, Semenov., Rev. russe d'Ent. vol. i, pp. 98 and 259. (1901.) (Corea.)

Forficula bicuspis, Stål, in Eugenies Resa, Ins. p. 301, (d). (1860.) (Java.)

\section{TABLE OF SPECIES.}

1. Segmentum ultimum abdominale supra medium spinis 2 fortibus verticalibus armatum . . . . 1. bicuspis, Stål.

* Gr. $\tau \iota \mu \omega^{\prime} \mu \epsilon \nu o s=$ respected. 


\subsection{Segmentum ultimum abdominale inerme.}

2. Forceps prope medium dentatus

2.2. Forceps prope apicem armatus
2. oannes, Burr.

3. komarowi, Semenov.

\section{Sub-family 3.-EUDOHRNIIN AE.}

\section{Genus Eudohrnia, nov. gen.}

Corpus cylindricum, elongatum ; antennæ sat robustæ; segmentum primum validum, robustum, quadratum, carinatum, inter carinulas sulculatum; segmento 2 minimo, globoso; 3 elongato, apice clavato; 4 elongato, valido ; 5 longiori ; ceteris gradatim elongatis et conicis ; caput globosum, læve, suturis obsoletis : pronotum quadratum, margine antico recto, postico rotundato: elytra sat rugulosa, carinula humerali sat acuta, brevissima : alæ longæ; pedes longi ; abdomen cylindricum, punctulatum; segmentum ultimum dorsale of lævius, minus dense punctulatum, breve, latum, medio impressum, vix tuberculatum ; pygidium $q$ declive, angustum : pygidium of breve, latum, bi-acuminatum: $q$ parvum, angustum, globosum : forcipis bracchia of valde elongata, horizontalia, subrecta, gracilia, basi triquetra, dente uno parvo medio armata; $q$ recta, subcontigua, simplicia, inermia.

The body is so differently shaped in the insect known as Anechura metallica, the forceps and the general colour so different, that I consider it generically quite distinct from true Anechura: this opinion is confirmed by the peculiar carinated first segment of the antennæ, which is quite distinctive.

Type.-Forficula metallica, Dohrn, Stett. ent Zeit., vol. xxvi, p. 9. (1865.) (Himalayas, Burmah.)

\section{Sub-family 4.-DIAPERASTICIN AE.}

The species which I range in this family are rightly separated from Apterygida by Verhoeff, but that author wrongly revived the name of Sphingolabis, Borm., which must be reserved for those species which are related to the type of Sphingolabis, namely, Sph. furcifera, Borm., which is the male of Sph. semifulva, Borm., which latter must stand, as I have shown elsewhere (1905, Ann. Mag. N.H., ser. 7, vol. xvi, p. 495).

At present it only includes certain African earwigs which fall into the genus Diaperasticus.

TRANS. ENT. SOC. LOND. 1907.-PART I. (JUNE) 7 


\section{Genus Diaperasticus, ${ }^{*}$ nov. gen.}

Corpus sat depressum; antennæ segmentis 4 et 5 cylindricis, gradatim elongatis; elytra et alæ perfecte explicatæ; pedes breves, femoribus plus minus incrassatis; pygidium breve, latum, transversum, depressum, haud spinosum; forcipis bracchia of gracilia, sat elongata.

Type.-Sphingolabis sansibarica, Karsch, in Berl. ent. Zeitschr., vol. xxx, p. 90, Pl. III, fig. 8, 今. (1886.) (Zanzibar.)

This genus will also include :-

Apterygida mackinderi, Burr, Ann. Mag. N. H., ser. 7, vol. vi, p. 83, Pl. IV, fig. 3a, 3. (1900.) (British East Africa). $\dagger$

Apterygida bonchampsi, Burr, Tr. Ent. Soc. Lond., p. 317. (1904.) (Abyssinia.)

Forficula erythrocephala, Olivier (nec Fabr.), Enc. Méth. vol. vi, p. 468. (1791.) (Africa and Madagascar.)

\section{TABLE OF SPECIES.}

1. Elytra flava, rufo-vittata.

2. Forcipis bracchia of margine interno haud dentato, crenulato . . . .

2.2. Forcipis bracchia apicem versus margine interno dentata

1. erythrocephala, Oliv.

1.1. Elytra unicoloria, fusca.

2. Corpus sat robustum; forceps incrassatus, medio fortiter dentatus

2.2. Corpus gracile; forceps gracilis, dente medio parvo, fere obsoleto . 4. sansibarica, Karsch.

\section{Sub-family 5.-OPISTHOCOSMIIN AE.}

This sub-family is used in a very restricted sense, as very many new genera must be formed for the reception of species which were formerly included in the cumbrous and very heterogenous Opisthocosmia, and many of the former members of that genus, in its widest sense, must be removed to other sub-families.

* Gr. $\delta \iota \alpha \pi \epsilon \rho \sigma \sigma \tau \iota \kappa o ́ s=$ penetrating.

$\dagger$ Probably this species is a large light-coloured variety of $D$. sansibarica, Karsch. 
In its restricted sense, this sub-family includes the true Opisthocosmia and its immediate allies, genera, that is to say, in which the feet are long and slender, the pygidium very short, barely distinguishable nor even not visible, and the anal segment very strongly narrowed and sloping in both sexes; the forceps are usually long, slender, and often armed with numerous teeth pointing in various directions.

\section{TABLE OF GENERA.}

1. Elytra haud carinata.

2. Pronotum capite angustius; (pedes gracillimi) . . . . . . .

1. Opisthocosmia, Dohrn.

2.2 Pronotum capite haud angustius.

3. Segmentum ultimum ventrale inerme.

4. Pygidium bifidum . . . .

4.4. Pygidium parvum, obtusum

3.3. Segmentum ultimum ventrale processu utrinque armatum.

1.1. Elytra costa carinata.

2. Pronotum capite angustius . . . 5. Emboros, n.

2.2. Pronotum capite haud vel vix angustius.

3. Alæ perfecte explicatæ; genus americanum

2. Lipodes, $n$.

3. Hypurgus, $n$.

4. Sarcinatrix, Rehn,

3. Alæ abortivæ; genus javanum 7. Cosmiella, Verhoeff.

\section{Genus 1.-Opisthocosmia, Dohrn.}

Statura gracili ; antennæ 10-12-segmentatæ; segmentis omnibus tenuibus, cylindricis, gracilibus ; segmento 3 quam primum dimidio breviori ; 4 quam 3 longiori ; 5 quam 4 longiori : caput tumidum, suturis distincte impressis, pone oculos tumido-elevatum ; pronotum capite distincte angustius, longius quam latius, margine antico recto, postico ovato, postice subangustatum; prozon atumida, metazona ampla, deplanata, lateribus reflexis; elytra ad humeros lata, apicem versus subangustata, lævia, margine exteriori distincta plicata, carinula humerali autem supra humeros ipsos haud producta; margine postico emarginata vel truncata; alæ longæ; pedes longi, gracillimi ; femora vix incrassata ; tibiæ superne teretes, compressæ ; tarsi graciles, segmento primo cetera unita æquanti vel superanti; abdomen basi gracile, medio subdilatatum, haud deplanatum, valde convexum, plicis lateralibus distinctis; lateribus ipsis inermibus, 


\section{Mr. Malcolm Burr's Preliminary Revision of the}

tuberculis nullis instructis: segmentum ultimum dorsale of angustatum, declive; $q$ etiam angustius ; pygidium of haud prominens ; forcipis bracchia gracilia elongata: of basi remota vel subcontigua, recta, vel sinuata ; a latere visa recta vel valde sinuata, dentata ; $q$ recta, simplicia, subcontigua, inermia, gracillima.

Type of the genus.-Opisthocosmia centurio, Dohrn. Stett. ent. Zeit., vol. xxvi, p. 79. (1865.) (Borneo.)

This genus formerly included a large number of very different species, so that it is necessary to subdivide it to a considerable extent, and to confine it to those species which resemble the type, 0 . centurio, in the extremely slender form and slender antennæ, with regularly lengthening segments, and in the narrow elongate pronotum.

In its restricted sense, this genus now includes the following species :-

\section{TABLE OF SPECIES.}

1. Elytra et alæ rufo-maculatæ.

2. Forceps valde flexuosus et dentatus;

statura majore ; species borneensis . 1. centurio, Dorhn.

2.2. Forceps subrectus, inermis; statura gracili; species africana . . 2. formosa, Burr.

1.1. Elytra unicoloria vel vittata.

2. Elytra unicoloria nigra.

3. Forceps ơ valde flexuosus ac dentatus

3.3. Forceps ơ contiguus, rectus, apice ipso arcuatus . . . . . .

3. cervipyga, Kirby.

4. erroris, Burr.

2.2. Elytra testacea vel rufescentia, vittata.

3. Elytra testacea, fuscovittata; statura parva (12.5 mm.) . . . . . 5. ceylonica, Dohrn.

3.3. Elytra rufa, anguste nigrovittata ; statura majore (15 mm.) . . . 6. armata, Haan.

Genus 2.-Lipodes, * nov. gen.

Statura robusta ; abdomen sat depressum, medio valde dilatatum, apicem versus attenuatum; caput per suturas profundas in tres partes divisum; pygidium persicuum, profunde fissum; forcipis bracchia sensim arcuata, inernia.

The erection of this new genus is necessary for the * Gr. $\lambda \iota \pi \omega \delta \eta s=$ fat. 
insect which I have described as Opisthocosmia vivax; in its general appearance it appears to be distinctly related to the genus Opisthocosmia but it differs in the depressed abdomen, in this respect affording a transition towards the Ancistrogastrine, but in other respects it appears to be referable to this group; the sutures of the head are very deep and well marked, dividing the head into three distinct divisions; the divided bifid pygidium is characteristic.

The unique specimen, which is in the Calcutta Museum, is unfortunately broken, so that it is not possible to determine the sex with satisfaction; the well-marked characters point to a male, but perhaps the simple form of the forceps implies the opposite. In my original description, I regarded it as a female, but upon further consideration I am inclined to consider it a male.

It is unfortunate that further material has not come to hand since, in order to locate its position with accuracy.

Type of the genus.-Opisthocosmia vivax, Burr, Journ. Proc. Asiat. Soc., Bengal, N. S. vol. i, No. 2, p. 30. (1905.) (India.)

\section{Genus 3.-Hypurgus, ${ }^{*}$ nov. gen.}

Antennæ 12-13-segmentatæ, graciles, segmentis gradatim elongatis cylindricis, 4 quam 3 sublongiori, 5 quam 4, etc.; caput læve, suturis obsoletis; pronotum capite haud angustius, subquadratum, margine postico rotundatum, vel semilunare; margine antico truncato ; prozona tumida, metazona plana, lateribus reflexis ; elytra ampla, lata, humeris latis, carina exteriori nulla ; ab humeris attenuata, margine postico truncata vel subemarginata; alæ perfecte explicatæ, longæ vel abbreviatæ; pedes graciles, longi, femoribus haud incrassatis; tibiis integris; abdomen basi constrictum et angustum, convexum, medio plus minus dilatatum, tuberculis pliciformibus distinctis, segmentis 5-6-7-8-inermibus, apice attenuatum ; segmentum ultimum dorsale angustatum, declive, margine postico incrassato, obtuse tuberculato; $q$ angustatum, minus fortiter tuberculatum ; pygidium nullum vel vix perspicuum, minimum, brevissimum, obtusum ; forcipis bracchia of elongata, paullo curvata, vix arcuata, sat fortia, basi subcontigua, dentibus nonnullis interdum margine interno armata, apicem versus sæpe sat arcuata ; $q$ typicæ, graciles, recta, inermia.

In this genus are included those former species of

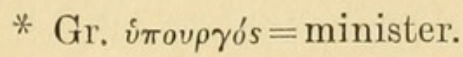


Opisthocosmia in which the pronotum is more or less square and not distinctly narrower than the head; the antennæ are the same as in true Opisthocosmia, but perhaps a little less slender, and the segments proportionately shorter; the forceps are simpler than in true Opisthocosmia and the feet are somewhat less slender and shorter.

The type of the genus.-Opisthocosmia humeralis, Kirby, Journ. Linn. Soc., vol. xxiii, p. 523, o. (1891.) (Ceylon).

\section{TABLE OF SPECIES.}

1. Pronotum subquadratum.

2. Elytra et alæ flavo-maculata . . 1. humeralis, Kirby.

2.2. Elytra vittata, haud maculata.

3. Alæ perfecte explicatæ; species madecassa. . . . .

3.3. Alæ deficientes; species ethiopica . . . . . . . 3. micheli, Burr.

1.1. Pronotum semilunare.

2. Rufo-testacea, rubro-variegata; forceps rufescens . . . . . . . . .

2.2. Atra, nitida; forcipe pedibusque læte rubris . . . . . . . 5. biroi, Burr.

\section{Genus 4:-Sarcinatrix, Rehn.}

Ab Opisthocosmia differt lamina subgenitali (segmento ultimo ventrali) $\delta$ angulis postico-exterioribus in processus tuberculiformes productis.

Sarcinatrix sub-genus, Rehn, Proc. Ac. Nat. Phil., p. 308. (1903.)

Rehn suggested this name for a sub-genus which he characterised by the processes of the subgenital lamina of the male, which is produced into a "recurved spiniform process, which flank the lateral base of the forceps" ; in the typical species described by him, the forceps of the male are parallel throughout their entire length; but this is not a generic character, for in my collection I have a second species in which the forceps are distinctly bowed.

Type of the genus.-Opisthocosmia (Sarcinatrix) anomalia, Rehn, Proc. Ac. Nat. Phil., p. 308. (1903.) (Costa Rica.) 


\section{TABLE OF SPECIES.}

1. Forcipis bracchia recta, parallela, haud dentata, margine interno crenulato-dentata.

1.1. Forceps basi leviter divergentia, tum convergentia; margine interno basi ipso dente armata : dehinc teretia . . . 2. rehni, sp. n.

\section{Sarcinatrix rehni, sp. n.}

Colore fusco-testaceo; antennæ 12-segmentatæ, typicæ; caput læve, depressum, suturis obsoletis, margine postico medio incrassato; pronotum quam caput æque latum, subquadratum, sublatius quam longius; margine antico recto, postico rotundato, lateribus rectis ; prozona tumida, sutura distincta ; metazona lata, plana; prozona a metazonâ distincte sejuncta ; lateribus late reflexis ; medio castaneum, lateribus pellicidis : elytra lævia, unicoloria, testacea: alæ longæ, fusco-testaceæ, basi indistincte pallido flavo-maculatæ; pedes testacei : abdomen castaneum, sat latum, plicis lateralibus distinctis ; segmentis 5 et 6 lateribus subreflexis, subtuberculatis $\delta$ : segmentum ultimum dorsale of transversum, magnum, postice quam antice angustius, margine postico recto, medio impresso, $q$ valde angustatum, simplex : pygidium of haud perspicuum; $q$ minutum, conicum: segmentum penultimum ventrale of rotundatum; segmentum ultimum ventrale ô apice profunde fissum, angulis posticoexternis in processum tuberculiforme acutum reflexum productis, of: $q$ inerme ; forcipis bracchia of basi haud contigua, sat incrassata, prope basin margine interno dente acuto armata; primum leviter divergentia per tertiam partem longitudinis, deinde subangulatim incurva, subrecta, sensim convergentia, inermia, apice ipso mucronata, decussata ; $q$ subcontigua, recta, gracilia, inermia.

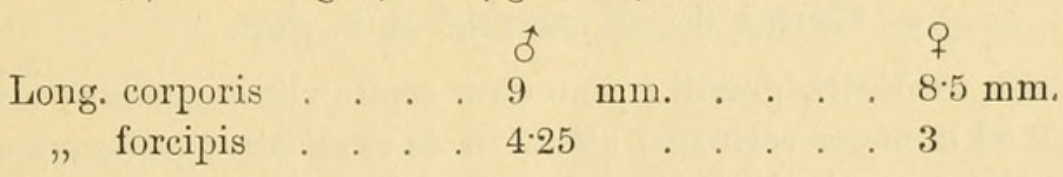

Patria: San Esteban (Simon, iii, 83. of types in coll. mea, ex coll. de Bormans).

Differs from $S$. anomalia in the non-parallel forceps.

\section{Genus 5.-Emboros, * nov. gen.}

Statura minore; antennæ 10-segmentatæ; segmento $4=3 ; 5$ quam 4 et quam 3 longiori : caput globosum, tumidum, nitidum : pronotum capite subangustius, longius quam latius, rectangulare, margine antico

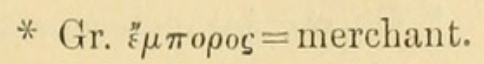


recto, postico subconvexo, lateribus rectis ; prozona tumida, sutura distincta, lateribus reflexis: scutellum nullum; elytra brevia, carinula humerali ad apicem elytri attingenti, margine postico truncato; alæ nullæ; pedes longi, graciles, tarsorum segemento primo cetera unita superanti; abdomen subcylindricum, convexum, plicis lateralibus distinctis, integrum; segmentum ultimum dorsale fo angustatum, declive, margine postico medio impresso, utrinque tuberculato; $q$ angustius, inerme; forcipis bracchia sat valida, subrecta, basi remota, sensim convergentia, rotundata; $q$ gracilia, attenuata, contigua.

Type of the genus.-Opisthocosmia dubia, Borm., Ann. Mus. Civ. Gen. xxxiv, p. 399, ․ (1894.) (Burmah.)

This genus removes from Opisthocosmia the wingless species described by de Bormans under the name dubia; it resembles true Opisthocosmia in every respect except the form of the elytra, in which it approaches the large and stout Skendyle, from which it differs in the narrow and somewhat elongated pronotum; the elytra are broad, coriaceous, with a sharp keel on the outer edge running the whole length of the elytra; the general form of the forceps also recalls Skendyle.

Verhoeff included this species with the other wingless forms previously included in Opisthocosmia, in his genus Cosmiella, characterised by the keeled elytra and absence of wings; but Kirby fixed O. rebus, Burr, as the type of Cosmiella, from which this species must be removed by its long and narrow pronotum, which approaches true Opisthocosmia.

\section{Genus 6.-Kleter, ${ }^{*}$ nov. gen.}

Statura mediocri, gracili; pronotum capite vix angustius; elytra tantum ad humeros carinata; alæ perfecte explicatæ; pedes graciles, longi; abdomen vix dilatatum, subcylindricum ; segmentis lateribus 4- 7 plicis recurvis depressis instructis; segmentum anale haud angustatum, transversum; forcipis bracchia elongata, gracilia, spinata.

Type of the genus.-Opisthocosmia amasonensis, Borm. and Burr, Ann. Mag. N. H. ser. 7, vol. iii, p. 164. (1899.) (Upper Amazons.)

This genus is a transition between the Opisthocosmiina * Gr. $\kappa \lambda \eta \tau \dot{\eta} \rho=$ policeman. 
and the Ancistrogastrinæ; in the elongate forceps, slightly dilated body and scarcely keeled elytra it recalls the former, but in the incipient lateral folds of the abdomen and the form of the last dorsal segment, and also the form of the apex of the male forceps, it approaches the latter.

\section{Genus 7.-Cosmiella, Verhoeff.}

Antennæ 10-segmentatæ, segmentis 3, 4 et 5 subæquantibus, longis, cylindricis; pronotum caput latitudine subæquans, haud longius quam latius, subquadratum ; elytra lata, carinula humerali sat distincta, per dimidium elytri percurrenti ; alæ nullæ ; abdomen convexum, medio dilatatum ; plicis lateralibus distinctis ; segmentis lateribus inermibus; segmentum ultimum dorsale of angustatum, tuberculis duobus vix elevatis instructum ; forcipis bracchia $\delta$ basi contigua, valde elongata, a basi divergentia, tum arcuatim incurva, margine superiori dente armata; $q$ simplicia.

This genus was erected by Verhoeff for the wingless species of Opisthocosmia which have a keel more or less pronounced on the elytra; Kirby fixed O. rebus, Burr, as the type of the genus; $O$. dubic was included by Verhoeff upon the strength of de Bormans' description, but on account of its narrow pronotum, it must be removed; in the shape of the pronotum and elytra this genus approaches Ancistrogaster, but in the form of the body and forceps it resembles Opisthocosmia ; it is a passage between these two chief genera.

It contains the single species 0 . rebus, Burr, fixed by Kirby as the type. C. aptera, Verhoeff, is removed to Skendyle, q.v.

\section{Sub-family 6.-ANCISTROGASTRIN AE.}

The essential character which distinguishes this subfamily from the preceding is the form of the anal segment, which is transverse, much broader than long.

The sides of the abdomen are often recurved in the form of depressed sickle-shaped hooks, and the forceps of the male are frequently bowed into a characteristic lozengeshaped area. In most genera the elytra are strongly keeled.

The genera are all American. 


\section{TABLE OF GENERA.}

1. Elytra haud carinata . . . . 1. Sarakas, n.

1.1. Elytra carinata.

2. Elytra tantum per dimidium longitudinis carinata . . .

2.2. Elytra per totam longitudinem carinata.

3. Elytra trapezoidea; rudimentaria ; alæ nullæ . . . . 3. Praos, n.

3.3. Elytra perfecte explicatæ.

4. Abdomen lateribus inermibus . . . . 4. Vlax, n.

4.4. Abdomen lateribus in spinas et mucrones productis

\section{Genus 1.-SARAKAS, ${ }^{*}$ nov. gen.}

Ancistrogastri vicinum genus, sed :-elytra haud carinata ; lateribus abdominis minus fortiter armatis, vix tuberculatis, vix mucronatis.

Type of the genus.-Opisthocosmia devians, Dohrn., 1865, Stett. ent. Zeit. vol. xxvi, p. 79. (Brazil.)

The genus is characterised by the absence of keels at the shoulder of the elytra; the sides of the abdomen are not strongly hooked but armed with tubercles.

It includes also Opisthocosmia aterrima, Borm., Ann. Soc. Ent. Belg. xxvii, p. 83 (1883), and perhaps O. longipes, Haan.

\section{Genus 2.-Osteulcus, $\uparrow$ nov. gen.}

Antennæ gradatim elongatæ; pronotum sublatius quam longius, planum : elytra punctulata, subquadrata, brevia, margine postico oblique truncata; costa humerali ad humeros carinata, carina in medio elytri evanescenti; alæ nullæ; pedes graciles, sat longi; abdomen basi angustum, medio fortiter dilatatum, sat depressum ; apicem versus attenuatum; segmentum ultimum dorsale subangustatum, transversum, latum; tubereulis lateralibus distinctis ; segmentis 5, 6 et 7 etiam tuberculata; pygidium haud perspicuum ; forcipis bracchia of sat robusta, depressa, basi remota et divergentia,

\footnotetext{
* бápaкas=wood-eater.

$\dagger \grave{o} \sigma \tau \varepsilon o v \lambda \kappa o ́ s=$ forceps.
} 
tum angulatim incurva, convergentia, in tertia parte apicali recta, apice mucronata ; $q$ recta, simplicia.

Type of the genus.-Ancistrogaster kervillei, Burr, Ann. Mag. N. H. ser. 7, vol. xvi, p. 490. (1905.) (Venezuela.)

In appearance resembles Proos, but the elytra are complete, the keel dies out half-way down the elytra, the abdomen is depressed and laterally hooked, and the forceps bowed strongly outwards and inwards in a lozenge form.

In general appearance this genus has even all the aspect of a typical Ancistrogaster, but in the feeble carina of the elytra, in the attenuate abdomen and somewhat narrowed last dorsal segment, it approaches the Opisthocosmiinx, but the depressed and dilated abdomen, and the form of the forceps are characteristic of Ancistrogastrinx; the last dorsal segment, although somewhat attenuated, is still much broader than long, distinctly transverse, and rectangular.

The single species, recorded from Venezuela, is very distinct.

It differs from Praos in the complete elytra, with a shorter costal carina, in the less sharply flattened abdomen, and the strongly bowed forceps, which include a lozengeshaped area; from Ancistrogaster, Vlax and Sarakas it differs in the absence of wings and form of the carina of the elytra.

\section{Genus 3.-Praos,* nov. gen.}

Corpus depressum; antennæ graciles; caput læve, margine postico emarginato; pronotum quadratum, marginibus omnibus rectis, sublatius quam longius, deplanatum ; elytra rudimentaria, trapezoidea, margine externo usque ad apicem carinata, margine postico oblique truncata, margine interno quam externo multo brevius, scutellum sat magnum triangulare efficientia ; alæ nullæ ; pedes longi, graciles, haud incrassati; abdomen valde deplanatum et dilatatum, plicis lateralibus distinctis ; lateribus segmentorum 3-6 tuberculis distinctis instructum; segmentis 7 et 8 lateribus acute recurvis; segmentum ultimum dorsale of breve, latum, valde transversum, medio impresso, bituberculato, angulis externis carinatis; forcipis bracchia basi valde remota, depressa, arcuatim incurva, intus dentata, apice mucronata.

Type of the genus.-Ancistrogaster perdita, Borelli, Boll.

$$
\text { * Gr. } \pi \rho \text { ạos = meek. }
$$




\section{Mr. Malcolm Burr's Preliminary Revision of the}

Mus. Zool. Torino, vol. xxi, no. 531, p. 16. (1906.) (Costa Rica.)

The only known species of this genus very closely resembles $A$. impennis, Borm., and under that name I received a specimen from de Bormans' collection; on comparing, however, with the type of impennis, in the Biologia Centrali-Americana collection, it is obviously different; it is remarkable for the flattened and dilated abdomen, and trapezoid elytra, which are cut away at the basal posterior angle, to show a small scutellum. It has since been described and discussed by Borelli (l.c.).

\section{Genus 4.-VLAX,* nov. gen.}

Statura minore; corpus minus depressum et minus dilatatum; abdomen of lateribus in mucrones acutos recurvos haud productis sed integris, inermibus, vel paullo angulatis vel tuberculis instructis; ceteris cum Ancistrogastre congruet.

Type of the genus.-Ancistrogaster championi, Bormans, 1893, Biol. Centr.-Amer. Orth., p. 10, Pl. II, fig. 13, 今. (Panama.)

This removes from Ancistrogaster those small, pale species, with the abdomen but little dilated, and the sides of the abdominal segments not curved backwards into flattened and sharp hooks, but furnished with blunt tubercles.

A. tolteca, Dohrn., and A. intermedius, Burr, will also fall into this genus.

\section{Genus 5.-Ancistrogaster, Stail.}

Antennæ 10-12 segmentatæ; segmentis 3 et 4 subæquantibus; ceteris elongatis, cylindricis; caput subtumidum, margine postico emarginato; pronotum caput latitudine æquans, antice truncatum, postice rotundatum; elytra ad humeros rotundata, lata, margine postico truncato vel emarginato: carinula humerali acuta, usque ad marginem posticum elytri percurrenti: alæ longæ; pedes graciles; femora vix incrassata; tarsorum segmentum primum cetera duo unita longitudine æquans: abdomen depressum, basi angustum, medio valde dilatatum, ante apicem iterum angustatum ; plicis lateralibus distinctis : of segmentorum latera producta, in mucrones valde deplanatos, acutos et recurvos producta ; $q$ abdomen inerme, minus dilatatum, minus depressum : segmentum ultimum dorsale $\delta$ breve,

* Gr. $\beta \lambda \alpha \dot{\xi} \xi=$ simpleton. 
transversum, rectangulare ; $q$ valde angustatum : forcipis bracchia o basi subcontigua, primum divergentia, in dimidio longitudinis repente incurva; margine interno prope basin saepius dente forti armata, apice incrassata et bimucronata: $q$ recta, simplicia, gracilia, inermia.

Type of the genus.-Ancistrogaster luctuosus, Stål, 1855, Ofv. Vet. Akad. Forh., vol. xii, p. 349, §. (Brazil.)

I have retained this genus only for the typical species with the sides of the abdominal segments recurved into depressed sickle-like hooks.

\section{Sub-family 7.--FORFICULINAE.}

I use this sub-family in a very restricted sense, as including the typical genus Forficula, Linn., and the closely allied Apterygida, Westw., sensu stricto. It is characterised by the form of the antennæ, in which the fourth segment is much shorter than the third, and only half as long as the fifth.

\section{TABLE OF GENERA.}

1. Forcipis bracchia of basi dilatata et de$\begin{array}{lllll}\text { planata } \quad \ldots & \ldots & \ldots & \ldots\end{array}$

2. Forcipis bracchia of basi remota, gracilia, nec deplanata, nec dilatata... $\quad \ldots \quad$ 2. Apterygida, Westw.

Genus 6.-Forficula, Linn.

Corpus convexum ; caput cordiforme, globosum suturis sæpe indistinctis; antennæ 10-15-segmentatæ ; 1 magnum, incrassatum ; 2 minimum, globosum ; 3 longum, primum subæquans, apice paullo incrassatum ; 4 quam 3 dimidio brevius ; 5 sensim longius; cetera gradatim longiora, subclavata; pronotum sæpius capite angustius, margine antico truncato; marginibus lateralibus aut parallelis, aut convexis ; margine postico rotundato ; sæpius subquadratum, necnon latius quam longius, aut dimidio postico toto late rotundato, arcuato; prozona plus minus tumida, metazona deplanata ; marginibus lateralibus paullo reflexis : elytra perfecte explicata, sat longa, vel brevia, truncata ; carinula humerali inconspicua, carina ipsa nulla, sed elytra a humeris ad apicem sensim plicata; alæ aut abbreviatæ, aut longæ, sæpius prominentes : pedes typici, femoribus haud valde incrassatis ; tarsorum segmentum 3 quam primum longius; segmentum 2 latum, dilatatum, bilobum, cordiforme; abdomen circa medium subdilatatum, plicis lateralibus segmentorum 2 et 3 distinctis : segmentum ultimum dorsale of magnum, quadratum, margine postico sæpe 
tuberculatum ; $\uparrow$, angustius, simplicius: pygidium parvum, globosom, vel valde productum, acuminatum, vel nullum; forcipis bracchia of in parte basali valde deplanata et dilatata, hac parte dilatata margine interno sæpe crenulata et dente terminata, vel inermi ; dehinc attenuata, subrecta, aut arcuatim curvata et inermia ; ○ subrecta, subcontigua, inermia.

This large and homogeneous genus is well characterised by the forceps of the male, in which the branches are flattened and broadened in the basal portion, as in the familiar typical species, $F$. auricularia, Linn. It contains a large number of species occurring in various parts of the Old World.

It is the typical genus of the Order, and in the typical species, F. auricularia, Linn., the characters are very well marked. The genus is represented in nearly every part of the globe, but the species are most numerous in the Old World. The discrimination of the species is often rather subtle, and the shape of the forceps must be employed with care and discretion; these vary considerably in length, showing the two forms macrolatia and cyclolabia; the latter appears to be the normal form, and the former a more virile robust race; in the common species, the macrolabia form appears to occur chiefly in islands and in mountains, and the ordinary form is more semi-domesticated in its habits. The elongation of the forceps is generally accompanied by the more robust build of body, and it also modifies the armature of the forceps, owing to the drawing out of this organ. The degree of curvature also varies, more especially in $F$. lurida, which gives the different varieties a very different appearance, which is often misleading.

The type of the genus is Forficula auricularia, Linn., Syst. Nat. (ed. x) i, p. 423 (1758).

\section{TABLE OF SPECIES.}

1. Pronotum latius quam longius, trapezoidale.

2. Forcipis bracchia tantum in parte basali dilatata et deplanata.

3. Forcipis bracchia fortiter extus ac intus flexuosa, inermia; (colore toto atro; glabra; species Indiæ borealis) 
3. Forcipis bracchia subrecta.

4. Forceps margine interno prope basin denticulatus; elytra unicoloria; alæ longæ; species indica . . . . . . . . .

4.4. Forceps margine interno crenu2. mogul, Burr.

latus ; elytra maculata ; alæ breves; species hispanica et algerica . . . . . . .

2.2. Forceps bracchia saltem per quartam 3. ruficollis, Fabr. partem longitudinis dilatata ac deplanata ; species indicæ.

3. Pronotum semilunare, lateribus haud reflexis; pars dilatata forcipis dente obtuso terminata . .

3.3. Pronotum ovatum, tranversum, lateribus reflexis; pars dilatata forcipis dente acuto terminata .

4. beelzebub, Burr.

5. acer, Burr.

1.1. Pronotum semilunare, subquadratum, margine postico rotundato, æque latum ac longum.

2. Pronotum semicirculare, margine antico recto, postice semilunare, lateribus haud parallelis. (Statura minore ; elytra maculata.)

3. Corpus valde pubescens; forcipis bracchia paullo dilatata, parte basali in partem apicalem attenuatam sensim transeunti . . .

3.3. Corpus subglabrum; forcipis bracchia medio subito attenuata.

4. Elytra fusca, macula humerali pallida ornata ; species ceylonica

4.4. Elytra pallida, apicem versus infuscata; species Africæ meridionalis
6. ornata, Borm

7. greeni, sp. n.

8. picta, Kirby.

2.2. Pronotum subquadratum, lateribus subparallelis, margine postico rotundato.

3. Pygidium valde prominens.

4. Pygidium triangulare, apice acutum (alæ abortivæ).

5. Pygidium lateribus haud incrassatis (colore nigrotestaceo, 
112 Mr. Malcolm Burr's Preliminary Revision of the

forcipe rubro; species lombokiana) . . . . . 9. miranda, Borm.

5.5. Pygidium utrinque incrassatum (colore testaceo ; species Europæ orientalis et Asiæ occidentalis).

6. Abdomen punctulatum; pars basalis forcipis longa, dente nullo terminata . . . 10. xtolica, Br.

6.6. Abdomen vix punctulatum; pars basalis forcipis brevis, angulo acuto dentiformi terminata . . 11. cancasica, Sem.

4.4. Pygidium apice truncatum vel obtusum.

5. Pygidium valde elongatum, linguæforme, apice haud truncatum ; pars dilatata forcipis longa ; alæ abortivæ; species Africa orientalis . . . . 12. sjöstedti, sp. n.

5.5. Pygidium brevius; pars dilatata forcipis brevis; alæ perfecte explicatæ ; species sinenses et japonicæ.

6. Pars dilatata forcipis apice obtuso-dentata ; species japonica . . . . . 13. mikado, Burr.

6.6. Pars dilatata forcipis apice haud dentata; species sinensis . . . . . 14. davidi, Burr.

3.3. Pygidium haud valde prominens.

4. Forceps tantum basi ipso dilatatus.

5. Forceps valde arcuatus, brevis ; alæ breves.

6. Elytra longiora; pedes unicolores . . . . . . 15. circinata, Fin.

6.6. Elytra brevia, truncata; pedes indistincte fuscoannulati . . . . 16. cabrerx, Bol.

5.5. Forceps parum curvatus, longior.

6. Alæ breves; species italica . 17. apennina, Costa. 6.6. Alæ longæ; species indica 18. ambigua, Burr. 
4.4. Forceps saltem per tertiam partem longitudinis dilatatus.

5. Forcipis pars dilatata longa, per dimidiam longitudinem forcipis producta, parallela ; bracchiis dehine minus arcuatis.

6. Pronotum quadratum, lateribus rectis, parallelis, angulis posticis rotundatis; alæ abortivæ (species Asiæ borealis) . . . . . 19. tomis, Kol.

6.6. Pronotum postice totum rotundatum, lateribus subrotundatis.

7. Elytra haud flavo-maculata.

8. Alæ abortivæ (species Africæ orientalis) . 20. rodziankoi, Sem.

8.8. Alæ perfecte explicatæ.

9. Pygidium obtusum; pronotum parvum; species africana . . 21. senegalensis, Serv.

9.9. Pygidium triangulare; pronotum magnum ; species novorossica . 22. pomerantrevi, Sem.

7.7. Elytra flavo-maculata.

8. Elytra et alæ longæ . . 23. lucasi, Dohrn.

8.8. Elytra et alæ breves . 24. barroisi, Bol.

5.5. Forcipis pars dilatata brevior, bracchiis dehine fortius arcuatis.

6. Pronotum magnum, longe super elytra productum

(Elytra et alæ longæ, testaceæ; species indica) . . 25. celer, Burr.

6.6. Pronotum minus longum, vix super elytra productum.

7. Elytra unicoloria.

8. Pars dilatata forcipis dente terminata.

9. Pars dilatata forcipis

TRANS. ENT. SOC. LOND. 1907.-PART I. (JUNE) \& 
114 Mr. Malcolm Burr's Preliminary Revision of the

usque ad secundam tertiam partem longitudinis producta; (alæ abortivæ ; statura minore) . . . 26. pubescens, Géné.

9.9. Pars dilatata forcipis vix ad dimidiam longitudinem producta.

10. Pars dilatata forcipis paullo ante dentem terminalem jam paullo attenuata 27. vicaria, Sem.

10.10. Pars dilatata forcipis dente ipso terminata.

11. Alæ perfecte explicatæ ; pronotum postice rotundatum . 28. auricularia, L.

11.11. Alæ nullæ; pronotum postice truncatum . 29. silana, Costa.

8.8. Pars dilatata forcipis inermis, dente nullo terminata.

9. Alæ nullæ.

10. Forcipis bracchia apice incurva, atque attingentia . . 30. decipiens, Géné.

10.10 Forcipis bracchia apiceincurva, sed haud attingentia.

11. Elytra quadrata . 31. lesnei, Finot.

11.11. Elytra trapezoidalia . . 32. canariensis, Burr.

\subsection{Alæ longæ.}

10. Forcipis bracchia

apice fere recta, vix incurva, haud attingentia;(species indica) . . . . 33, interrogans, Burr

10.10. Forcipis bracchia apice incurva, attingentia. 
Forficulidx and Chelisochidx, families of Dermatoptera. 115

11. Caput et pronotum atra ; (statura minore ; species indica) . . .

11.11. Caput rufum ; 34. planicollis,Kirby pronotum testaceum.

12. Forceps extus arcuatus . . 35. orientalis, Burr.

12.12. Forceps margine externo recto, tum incurva . . 36. lurida, Fisch.

7. Elytra maculata.

8. Pars dilatata forcipis dente horizontali terminata . 37. smyrnensis, Serv. 8.8. Pars dilatata forcipis dentibus parvis 2 erectis terminata

38. redempta, Burr.

Forficula greeni, sp. nov.

Statura minore; fusco-castaneo, pallido-maculato ; antennæ castaneæ, 12-segmentatæ; 3 sat longo; $5=3 ; 4$ dimidio breviori, conico ; ceteris subcylindricis, sat validis : caput læve, globosum, suturis obsoletis, fusco-ferrugineum: pronotum semilunare, caput latitudine æquans, margine antico truncato, postice late rotundato, lateribus rotundatis ; latius quam longius ; fusco-castaneum, lateribus pallidis ; prozona vix tumida, sutura mediana brevi, fere obsoleta, punctis impressis lateralibus nullis; elytra lævia, longa, fusco-castanea, medio macula magna pallida flava ornata ; alæ longæ, læves, flavæ, pallidæ, sutura et apice infuscatæ ; pedes breves, testacei; abdomen parallelum, plicis lateralibus distinctis, fusco-rufum vel rufo-fuscum, læve, nitidum; segmentum ultimum dorsale ô subquadratum, læve, medio impressum, margine postico utrinque tuberculo obtuso instructum ; $q$ minute punctulatum, minum læve, angustius tuberculis minoribus : pygidium of vix perspicuum, subglobosum ; q haud perspicuum : forcipis bracchia of basi dilatata et deplanata, hac parte margine interno crenulato; per tertiam partem longitudinis deplanata; dehinc attenuata, inermia, teretia, subrecta, apice sensim incurva; $q$ valida, depressa, subcontigua, subrecta, inermia, apice tantum paullo incurva.

Long. corporis of $9 \mathrm{~mm}$, q $8 \mathrm{~mm}$. ; forcipis of $2 \mathrm{~mm}$., o $1.5 \mathrm{~mm}$. 


\section{Mr. Malcolm Burr's Preliminary Revision of the}

Chelisoches pulchellus, Burr (nec Gerst.) Journ. Bombay N. H. Soc. xiv, p. 327 (1902).

Patria. Cexlon: Punduloya and Ambegammoa, fairly common (Coll. mea).

This species was confused by me with Chelisoches pulchellus, Gerst., and recorded as such in a paper on the earwigs of Ceylon (l.c.); I sent some specimens to de Bormans, who also identified them as Ch. pulchellus; but that is a West African species, and on comparing the Ceylon specimens with Gerstaecker's description, my doubt as to its identity is confirmed; the head of the African insect appears to be tumid behind the eyes, with distinct sutures, a feature very characteristic of Chelisoches, whereas the Ceylon specimens have the head perfectly smooth as in true Forficula; Ch. pulchellus has the pronotum "quadratisch," and not crescent-shaped; the organs of flight are yellowish with a dark brown band, whereas in the Ceylon specimens they are dark castaneous, with a large pale spot on the elytra, and the wings are pale yellow, with a brownish suture and apical speck; the form of the forceps seems to agree however; Gerstaecker's insect is only known to me from the description of that author.

$F$. greeni, which I am pleased to dedicate to my friend Mr. Ernest Green, who has procured me such interesting material from Ceylon, more closely resembles in size and colour $F$. ornata, which also has the same shaped pronotum.

\section{Forficula sjöstedti, sp. n.}

Statura mediocri, minus fortiori; antennæ 12-segmentatæ, segmentis subconicis, fusco-testaceis; caput læve; pronotum sublatius quam longius; postice rotundatum; elytra brevia, unicoloria ; alæ abortivæ ; pedes testacei ; abdomen typicum, castaneum, minutissime punctulatum ; segmentum ultimum rectangulare, punctulatum ; pygidium of elongato-productum, linguæforme, angustum, apice attenuatum et obtusum ; q breve, angustatum, apice truncatum ; forcipis bracchia of gracilia, per tertiam partem basalem margine interno deplanato ac dilatato, margine ipso crenulato, hac parte dente parvo obtuso terminata, dehinc attenuata, inermia, arcuata ; of, recta, simplicia. of $q$.

Long. corporis ơ 8.5-9·75 mm., q 8.5-9 mm.; forcipis of $3.5-6 \mathrm{~mm}$., ㅇ $1 \cdot 75-2 \mathrm{~mm}$. 
Hab. East Africa: Kilimandjaro, Kiboscho, at the highest limits of vegetation.

This species was discovered in great numbers by Dr. Yngve Sjöstedt, who has kindly given me permission to include its diagnosis in this paper. It will be more fully described and discussed in a work upon the results of Dr. Sjöstedt's travels in East Africa.

\section{Genus 2.-Apterygida, Westwood.}

The older authors included a large number of diversified and highly heterogeneous forms in this genus, which I have reduced to its narrowest limits, including only albipennis Meg, ${ }^{*}$ the typical species for which Westwood erected the genus.

The genus Sphingolabis, Borm., I formerly pointed out coincided with Apterygida unless the two species $S$. furcifera and $A$. albipennis could be shown to be not generically related to each other (Ann. Mag. N. H. ser. 7, vol. iv, 1899, p. 255). Sphingolabis was wrongly revived by Verhoeff for $S$. sansibarica, which is very different in structure from $S$. furciferc.

A. arachidis, Yers., has always been regarded as closely allied to $A$. albipennis, but the second tarsal segment has not that large and prominent lobe which is characteristic of this group of sub-families, from which it must consequently be removed. A.linearis and the other forms with a spiny pygidium I have placed together in a new genus.

The type is Forficula albipennis, Megerle apud Charp. Hor. Ent. p. 68 (1825), from Central Europe.

\section{Sub-family 8.-SKENDYLIN $A$.}

It is necessary to separate the species aptera, Verhoeff, from the genus Cosmiella, and as it does not fall naturally into any other group it is necessary to make a separate sub-family for its reception. The only known species recalls certain Ancistrogaster in appearance, and its affinities are undoubtedly with that genus, but the fourth antennal segment is somewhat shorter than the third, a fact which precludes it from that sub-family.

The form of the antennæ separates it from the Opisthocosmiinz.

* The name Forficula media is preoccupied by Marsham, Col, Brit. p. $530(1802)=$ Labia minor (L.). 
Genus 1.-SKEndyLE, * nov. gen.

Antennæ segmento quarto quam tertio subbreviori vel subæquanti, nequaquam longiori ; elytra in parte humerali per dimidium costæ carinata; alæ abortivæ; abdomen medio sat dilatatum, lateribus acute reflexis; segmentum anale breve, sat angustatum, transversum; foreipis bracchia subcontigua, valida.

This genus contains the single species described as Cosmiella aptera, Verhoeff, who, as we have seen, made a distinct genus for species of Opisthocosmia sensu latiori, without visible wings; but this insect differs in structure from C. rebus, the type of Cosmiella. There seems to be no doubt that the insect described as Ancistrogaster javana, Borm., 1903, Ann. Mag. N. H. ser. 7, vol. xi, p. 266, is identical, and therefore falls in favour of Verhoeff's prior name. It is a native of Java.

The type is Cosmiella aptera, Verhoeff, Zool. Anz. xxv, p. 195 (1902).

\section{Sub-family 9.-NEOLOBOPHORIN $A$.}

The species formerly included in Nelobophora, though evidently allied to Opisthocosmia, are nevertheless sufficiently distinct to merit a separate group. The Asiatic forms are undoubtedly generically distinct from the American species.

\section{TABLE OF GENERA.}

1. Pygidium bifidum; genus america-

num; segmentum anale quad- 1. Neolobophora, Scudd ratum.

1.1. Pygidium integrum; segmentum anale attenuatum, declive ; genera asiatica.

2. Costa elytrorum incrassata.

2. Liparura, n.

2.2. Costa elytrorum carinata, sed haud incrassata. . . . 3. Obelura, n.

\section{Genus 1.-Neolobophora, Scudder.}

This genus is now restricted to the American forms. It has been recently dealt with by me in the Ent. Mo. Mag. 1906 , p. 112.

$$
\text { * } \sigma \kappa \varepsilon \nu \delta \dot{v} \lambda \eta=\text { pincers. }
$$


The type of the genus is $N$. bogotenis, Scudd.; the other three described species are N. bicolor, Borelli, N. ruficeps, Burm., and N. borellii, Burr.

\section{Genus 2.-Liparura,* nov. gen.}

Pronotum latum, quadratum, lateribus subreflexis; scutello patente; elytra costa carinata, carina sat incrassata; abdomen punctatum; pedes longi, graciles ; segmentum anale valde attenuatum, declive ; forcipis bracchia of subcontigua, gracillima, elongata, sinuata ; $q$ recta, simplicia.

I form this genus for a pair in the Paris collection which I take to be Neolobophora asiatica of de Bormans, although the pair in question are from Northern India, and $N$. asiatica was described from Madras; it differs from the following genus in its stouter build, longer legs, punctated abdomen, reflexed borders of the pronotum, and by the strong costal carinæ of the elytra. I have not seen the type of de Bormans' species, but the pair in question agree perfectly with his description; the male is from Dardjiling, and the female from Bhoutan. There is nothing in de Bormans' description and illustration to show any generic distinction from $N$. tamul (q. v.), but the pair which I take to be his species are undoubtedly generically distinct.

The type is Neolobophora asiatica, Borm., Ann. Soc. Ent. Fr., 1897, p. 285, Pl. X, fig. 2, from Southern India.

\section{Genus 3.-Obelura, $†$ nov. gen.}

Statura minore, gracili ; antennæ 12-segmentatæ, typicæ, graciles : caput læve, tumidum, margine postico recto ; pronotum quam caput æque latum, marginibus omnibus rectis, quadratum, lateribus reflexis, vix tumidum; elytra rudimentaria, trapezoidea, margine externo usque ad apicem carinata, margine interno quam externo distincte breviori, scutellum parvum efficienti; margine postico oblique truncato ; alæ nullæ; pedes graciles; abdomen subdilatatum, plicis lateralibus distinctis, lateribus integris; segmentum ultimum dorsale valde angustatum, læve, inerme; forcipis bracchia of valde gracilia et elongata, basi subcontigua et margine superiori per quartam partem longitudinis carinata, dehinc valde attenuata, leviter arcuata, denticulata.

$$
\begin{aligned}
& * \lambda \iota \pi a \circ o ́ s=\text { fat ; ỡ } \rho a=\text { tail. } \\
& +\dot{o} \beta \varepsilon \lambda o ́ s=\text { spike ; ovं } \rho a=\text { tail. }
\end{aligned}
$$


This is for the reception of Neolobophora tamul, Burr, Journ. Bombay Soc. N. H. xiv, p. 67 (1902), from Ceylon, which is therefore the type.

$$
\text { Sub-family 10.-EPARCHIN } A \text {. }
$$

This sub-family consists of five new genera formed for the reception of several forms hitherto included in Opisthocosmia and in Apterygida, with the types of which they have little close relationship.

\section{TABLE OF GENERA.}

1. Abdomen segmento ultimo dorsali attenuato, declivi.

2. Pedes longi, graciles . . . . 1. Eparchus, n.

2.2. Pedes breves; femora antica incrassata . . . . . . . . .

2. Skalistes, n.

1.1. Abdomen segmento ultimo haud declivi, transverso.

2. Tibiæ superne sulcatæ

3. Rhadamanthus, n.

2.2. Tibiæ integræ.

3. Abdomen haud depressum; forceps prope basin dentatus, gracilis . .

3.3. Abdomen depressum; forceps propo basin subdilatatus ac basi ipso dentatus

\section{Elaunon, n.}

\section{Genus 1.-Eparchus,* nov. gen.}

Antennæ segmentis 3 et 4 subæquantibus; pronotum quam caput subæque latum; elytra et alæ perfecte explicatæ; elytra costa humerali haud carinata; abdomen convexum, subcylindricum paullo dilatatum ; pygidium varium, sed haud spinosum ; forcipis bracchia of elongata, gracilia. Segmentum anale declive, vel attenuatum; pedes longi graciles; abdomen lateribus tuberculis instructum.

This genus is made for the reception of a number of species formerly included in Opisthocosmia, with which it has undoubted affinities, but the pronotum is not notably narrow and the antennæ are different.

The type of the genus is Forficula insignis, Haan, Verh. Nat. Gesch. Orth., p. 243, Pl. XXIII, fig. 14 (1842), from Java.

* Gr. $\check{\varepsilon} \pi a \rho \chi o s=$ sub-prefect. 


\section{TABLE OF SPECIES OF EPARCHUS.}

1. Forcipis bracchia supra processu verticali clavato-obtuso armata . . . . . 1. insignis, Haan.

1.1. Forcipis bracchia of supra dentibus acutis armata,, vel inermia.

2 Abdomen læte nitens.

3. Corpus valde elongatum; æneo-nitens; forceps valde elongatus, vix arcuatus . . . . . . . . 2. nevilli, Burr.

3.3. Atra, haud æneo-nitens; forceps valde arcuatus . . . . . 3. lugens, Borm.

2.2. Corpus innitidum.

3. Statura minore $(6 \mathrm{~mm}$.$) . . . . 4. minuscula, Dohrn.$

3.3. Statura majore (10-13 mm.).

4. Colore castaneo.

5. Forceps inermis, valde curvatus 5. dux, Borm.

5.6. Forceps valde dentatus . . . 6. xsculapius, Burr.

4.4. Colore atro.

5. Pronotum albo-limbatum; elytra innitida . . . . . . . 7. shelfordi, Burr.

5.5. Pronotum totum atrum; elytra nitida . . . . . . 8. vicina, Burr.

Opisthocosmia bogotensis, Rehn, will probably fall into this genus.

\section{Genus 2.-Skalistes,* nov. gen.}

Pedes breves, femoribus incrassatis; segmentum anale declive attenuatum ; abdomen lateribus haud tuberculatis.

The type is Forficula lugubris, Dohrn., Stett. ent. Zeit. xxiv, p. 230, (1862), from Mexico.

This is formed for $F$. lugubris, Dohrn., which was formerly placed in Forficula in spite of its striking resemblance to certain species of Opisthocosmia; in the attenuate anal segment, it approaches that genus.

F. metrica, Rehn, appears to be a macrolabia variety of F. lugubris.

\section{Genus 3.-Rhadamanthus, nov. gen.}

Abdomen subcylindricum, haud depressum; segmento ultimo transverso, haud declivi ; forceps elongatus, of superne cristatus;

* Gr. $\sigma \kappa a \lambda \iota \sigma \tau i \dot{s}=$ weeder. 
pedes longi, femoribus incrassatis, tibiis superne sulcatis in dimidio apicali.

The type is Forficula lobophoroides, Dohrn., Stett. Ent. Zeit. xxvi, p. 96 (1865).

The only species falling in this genus is the rare and little known Forficula lobophoroides of Stal, from the Philippines. In appearance somewhat resembling certain black Chelisochidx, its affinities are undoubtedly with Forficula, while the long slender legs and forceps recall Opisthocosmia. I place it in this sub-family with some hesitation. It is curious that in the right antenna of a male in my collection, the fourth segment is noticeably shorter than the third, while in the left antennæ, the fourth is about the same length as the third, which is the case in both antennæ of a female which I possess; in a male in the British Museum the segments are almost of the same length, if anything the fourth is slightly longer than the third, and the fifth than the fourth; perhaps when we can examine more material, we shall be obliged to place it nearer to Opisthocosmia.

\section{Genus 4.-Kosmetor,* nov. gen.}

Abdomen cylindricum, vix dilatatum; segmentum anale transversum, vix declive; pedes graciles; forceps gracilis, attenuatus; tibiæ integræ, haud sulcatæ.

The species for which I have erected this genus were formerly placed in Opisthocosmia and in Apterygida, and they have certain superficial resemblances to the former, but in the form of the abdomen they more nearly approach to the typical form of Forficula, from which they differ in the long slender forceps and different antennæ.

The type of the genus Opisthocosmia annandalei, Burr, Trans. Ent. Soc. Lond. 1904, p. 311, from Siam.

All the species are from tropical Asia, and all have long slender forceps with one tooth.

\section{TABLE OF SPECIES.}

1. Abdomen læve, nitidum (caput, pedes, pronotum, alæ flavæ; elytra castanea). 1. poultoni, Burr.

1.1. Abdomen punctulatum (caput et pronotum castanea).

$$
\text { * Gr. } \kappa о \sigma \mu \dot{\eta} \tau \omega \rho=\text { overseer. }
$$


2. Pedes flavi, atro-geniculati ; alæ flavæ ; antennæ pallido-annulatæ . . . 2. annandalei, Burr.

2.2. Pedes unicolores sordide testacei; alæ fuscæ; antennæ haud annulatæ.

3. Forceps of intus unidentatus.

4. Elytra nigra; alæ nigræ, apice flavo-punctatæ; forceps of subrectus, subsinuatus . . . . 3. brahma, Burr.

4.4. Elytra fusca; alæ fuscæ, flavobinotatæ ; forceps elongatoovatus, haud sinuatus . . 4. vishnu, Burr.

3.3. Forceps of bidentatus . . . 5. temora, Burr.

\section{Genus 5.-Elaunon.**}

Cum genere precedenti congruet, sed, abdomen distincte depressum, parallelum, haud cylindricum; forcipis bracchia of basi ipso subdilatata atque intus dentata.

This genus is for Apterygida bipartita, Kirby, which approaches true Forficula and Apterygida, but the fourth segment of the antennæ is not sufficiently short to justify its being placed in the latter genus, and the dilatation of the forceps at the base is only incipient, being emphasised by the flattened triangular tooth there, so that the resemblance to the typical Forficula forceps is more apparent than real; but in the form of the abdomen and body generally, it is nearer to that group than to Eparchus.

The type is Sphingolabis bipartita, Kirby, Linn. Soc. Journ. Zool., xxiii, p. 526 (1891), from India and Ceylon.

$$
\text { Sub-family 11.-DORATINAE. }
$$

$$
\text { Genus.-DorU, † nov. gen. }
$$

Antennæ segmentis 4 et 3 subæquantibus; elytra haud carinata ; abdomen subparallelum, sat depressum ; segmentum anale transversum, depressum, haud declive; pygidium spinosum vel acutum ; forcipis bracchia $f$ gracilia, basi remota, haud dilatata.

I have separated into this group those species of Apterygida with a sharp, pointed or spiny pygidium; they all

* Gr. $e^{\lambda} \lambda a v ́ \nu \omega \nu=$ driving.

$\dagger$ Gr. $\delta$ o $\dot{v}=$ spear (cp. Latin genu and cornu). 
have a strong family likeness, and are undoubtedly related to Apterygida.

The type of the genus is Forficula linearis, Esch., Entomogr. p. 81 (1822), from Tropical America.

\section{TABLE OF SPECIES.}

1. Pygidium apice truncatum.

2. Forceps inermis; alæ longæ; species americana . . . . . . . 1. binotata, Kirby.

2.2. Forceps of dentatus; alæ abbreviatæ; species australica . . . . 2. subaptera, Kirby.

1.1. Pygidium apice acutum, conicum, vel spinosum.

2. Pygidium triangulare, acutum, sed haud spinosum.

3. Pygidium ơ carinatum; species africana . . . . . . . . . 3. protensa, Gerst.

3.3. Pygidium of haud carinatum; species americana . . . . 4. exilis, Scudder.

2.2. Pygidium of spinosum.

3. Forceps of basi dentatus. . . . 5. spiculifera, Kirb.

3.3. Forceps $f$ basi ipso haud dentatus.

4. Forceps $\delta$, a latere visus, valde sinuatus (alæ abbreviatæ) . . . 6. luteipennis, Serv.

4.4. Forceps $\delta^{f}$, a latere visus, paullo sinuatus, vel fere horizontalis.

5. Elytra unicoloria . . . . . 7. luteipes, Scudd.

5.5. Elytra maculata vel vittata.

6. Elytra maculata . . . . 8. bimaculata, Fabr. 6.6. Elytra vittata . . . 9. linearis, Esch.

\section{CHELISOCHID Æ.}

This family includes all those earwigs in which the second tarsal segment is produced into a narrow lobe beneath the third, that is, the two species of Auchenomus, Karsch, and some twenty odd species included in Chelisoches, Scudd.

The former genus requires no treatment at present; its species are few and individuals are rare in collections.

The twenty odd species of the Chelisoches are here divided for the first time into no less than nine genera, of which seven are new. I hope that all will stand the test of time.

The Chelisochide fall into two sub-families as follows:- 
1. Corpus valde depressum; pronotum antice valde angustatum (forceps valde tenuis, elongatus) . . . . . .

1. Auchenomine.

1.1. Corpus subdepressum; pronotum subquadratum vel ovatum, hand valde angustatum

2. Chelisochinæ.

The first sub-family includes only the genus Auchenomus, Karsch, which superficially strongly resembles Sparatta and its allies. It is with the Chelisochine only that this paper deals.

\section{TABLE OF GENERA.}

1. Carina externa elytrorum longa, usque ad apicem elytri percurrens ; (pedes longi, graciles).

2. Elytra quadrata, truncata; (statura mediocri; haud metallica; alæ abortivæ) . . . . . . . .

2.2. Elytra ampla, lata; (statura maxima ; metallica; alæ longæ) .

1.1. Carina humeralis externa elytrorum brevissima, tantum ad humeros ipsos situata.

2. Tibiæ superne in dimidio apicali deplanatæ et sulcatæ.

3. Tarsi longi, graciles; tibiæ longæ; (elytra et alæ metallica)

1. Kinesis, n. g.

2. Chelisochella, Verh.

3.3. Tarsi tibiæque breves.

4. Pronotum longius quam latius, vel saltem postice quam antice latius, trapezoidale. (Caput sæpius tumidum et impressum.)

5. Antennarum segmentum 4 conicum vel clavatum; (species majores; colore nigro vel fusco). . . .

3. Exypnus, n. g.

5.5. Antennarum segmentum

4. Chelisoches, Scudd. 4 cylindricum vel ovatum, haud clavatum; (statura mediocri vel 
parva ; colore brunneo, vel nigro, rufo variegato, vel testaceo).

6. Alatæ; elytra angulo basali rectangulari, scutello nullo; corpus haud cylindricum, sat latum et depressum; forceps validus, vel deplanatus, plus minns dentatus, et arcuatus .

6.6. Alæ nullæ; elytra angulo basali rotundato, scutellum parvum liberantia ; corpus valde cylindricum et elongatum; forceps gracillimus, elongatus, subrectus, haud dentatus . .

6. Solenosoma, n. g.

4.4. Pronotnm subquadratum, latius quam longius ; caput globosum, læve .

5. Proreus, n. g.

7. Enkrates, n. g.

2.2. Tibiæ superne integres, teretes, in apice ipso tantum deplanatæ.

3. Statura valida; forceps robustus; colore metallico; (pronotum postice dilatatum, trapezoidale) . . . . . . . . .

8. Adiathetus, n. g.

3.3. Statura debilis; colore haud metallico; forceps tenuis ; pronotum subovatum, postice haud dilatatum . . .

9. HАM $\Delta x \Delta \mathrm{s}$, n. g.

\section{Genus 1.-Kinesis, * nov. gen.}

Statura mediocri; antennæ segmento 3 sat brevi, quintum subæquanti; quarto paullo breviori, cylindrico; caput sublæve, suturis indistinctis vix impressum; pronotum trapezoidale, longius quam latius, parallelum, margine antico recto, angulis humeralibus distinctis, rectangularibus; lateribus rectis, reflexis, margine postico

* Gr. $\kappa^{i} \nu \eta \sigma \iota s=$ movement. 
ubrotundato ; prozona sat tumida, sutura mediana distincta, utrinque impressa; elytra brevia, truncata, quadrata, carina laterali acuta, per totam longitudinem elytri percurrenti; alæ abortivæ; abdomen punctulatum; segmentum ultimum dorsale of magnum, tumidum, transversum : $q$ declive, angustatum ; pygidium haud perspicuum; forcipis bracchia of basi remota, brevia, valida, incrassata, incurva, intus dentata; $q$ recta, gracilia, inermia.

This genus is well characterised by the form of the elytra which are almost square, with a sharp and very distinct carina along the edge, running throughout the length of the elytra; the wings are wanting in the only known species, which in general characters otherwise resembles Chelisoches.

The type, and only known species, is Chelisoches punctulatus, Burr, Ann. Mag. N. H. (6), xx, p. 315 (1897), from the Southern Colebes.

\section{Genus 2.-Chelisochella, Verhoeff.}

Statura maxima, valida ; antennarum segmentis 4 et 5 æque longis, unitis 3 superantibus : caput valde impressum at tumidum; pronotum caput latitudine æquans, postice haud dilatatum ; elytra lata, ampla, dilatata, nitentia, lævia, carina humerali per totam longitudinem percurrenti ; alæ longæ, nitidæ; abdomen validum ; pedes longi, graciles; tibiæ compressæ, integres, nec deplanatæ nec sulcatæ; tarsi longi; segmentum ultimum dorsale magnum, læve, tuberculatum; pygidium parvum breve; forcipis bracchia valida, elongata, depressa, margine interno valde dentata, margine interno depresso, acuto.

Chelisochella, Verhoeff, 1902, Zool. Anzeig., No. 665, p. 196.

This genus, very inaptly named by Verhoeff, for it contains the giant of the group, is characterised by the form of the elytra, which are broadened in the middle, and furnished with a lateral keel throughout their length. Verhoeff includes in it the species Chelisoches pulchripennis and glaucopterus, Borm., but he was evidently not familiar with the species, for they do not possess the essential character mentioned by him, that is, the long keel of the elytra; in other respects, C. pulchripennis approaches to this genus, that is, in colour and in the form of the feet; 


\section{Mr. Malcolm Burr's Preliminary Revision of the}

I propose for it a new genus intermediate between this and Chelisoches properly so called.

The type is Lobophora superba, Dohrn., Stett. Ent. Zeit. xxvi, p. 71 (1865), of which Ch. doriz, Borm., is probably the male.

\section{Genus 3.-Exypnus,* nov. gen.}

Colore fusco, æneo-nitido ; antennæ 20-segmentatæ, segmento 3 segmenta 4 et 5 unita æquanti ; $4=5$; 6 sublongiori ; 4 crasso, globoso ; caput tumidum, per suturas impressas divisum, margine postico excavato ; pronotum caput latitudine æquans, margine antico recto, medio in collem perductum ; lateribus parallelis, postice haud dilatatum, margine postico rotundato-truncato; elytra lata, apice truncata, carinula humerali brevissima; alæ longæ; pedes longi, graciles; tibiæ antice et intermediæ superne in dimidia apicali deplanatæ et sulcatæ; pygidium breve ; forcipis bracchia depressa, margine interno acuto ; of arcuatim incurva, intus dentata ; $q$ recta, gracilia, inermia.

Ch. pulchripennis, Borm., is included by Verhoeff in the preceding genus, but as it does not possess the characteristic sharp edge to the elytra, it cannot be placed there; it has, however, the broad elytra, tumid and impressed head, and long and slender feet of that genus, but the tibiæ are depressed and sulcate as in Chelisoches; the forceps of the female are simple as in Chelisoches, and not strongly toothed as in Chelisochella. It forms an intermediate genus between these two.

The type and only known species is Chelisoches pulchripennis, Borm., Ann. Soc. Ent. Belg., xxvii, p. 78, Pl. III, fig. 15, 1883, from the East Indies.

\section{Genus 4.-Chelisoches, Scudder.}

Statura mediocri; antennæ 15-20-segmentatæ; segmento 3 sat longo, 4 et 5 unita subbreviori ; segmento 4 conico, subclavato; 4 et 5 subæquantibus, ceteris longioribus; caput tumidum et impressum; postice plus minus excavatum; pronotum longius quam latius, postice paullo dilatatum, margine postico rotundato vel rotundato-emarginato; elytra angusta, carinula humerali brevi; haud metallica; alæ perfecte explicatæ; abdomen sat depressum, plicis lateralibus distinctis; segmentum ultimum dorsale of magnum, margine postico tuberculatum ; $q$ angustatum ; pedes breves, tarsis

$$
\text { * Gr. } \xi_{\xi} v \pi v 0 s=\text { brisk. }
$$


brevibus; tibiæ anticæ et intermediæ, necnon posticæ, superne in dimidio apicali deplanatæ et sulcatæ ; pygidium parvum; forcipis bracchia of elongata et gracilia, vel brevia, robusta, subrecta, vel arcuatim incurva; margine interno dentato depressa vel subtriquetra margine interno acuto ; $q$ subrecta, inermia, elongata, vix incurva.

This genus contains the typical species allied to $C h$. morio; the species are mostly dark in colour, if not quite black, though $C h$. plagiatus, while agreeing in structural characters, ditfers in its bright and variegated uniform.

The type is Forficula morio, Fabr., Syst. Ent., p. 270, No. 6, 1775. From the East Indies and Pacific Islands.

\section{TABLE OF SPECIES.}

1. Pronotum capite haud multo latius.

2. Pronotum elytra alæ læte metallica. 1. glaucopterus, Borm.

2.2. Color haud læte metallicus.

3. Forceps tenuis; pygidium bilobum . 2. ater, Borm.

3.3. Forceps validus; pygidium integrum.

4. Elytra et alæ nigræ; corpus nigrum, tarsis exceptis pallidis ; antennæ pallido-annulatæ . . 3. morio, Fabr.

4.4. Elytra colorata.

5. Corpus nigrum; elytra alæque auriantiacæ; species australica

5.5. Colore rufo, testaceo, flavo et fusco læte variegato; species africana . . . . . .

4. australicus, Gou.
1.1. Pronotum capite multo latius
6. malgachus, Borm.

5. plagiatus, Fairm.

Chelisoches stratioticus of Rehn is probably only a finely developed variety of $C h$. morio, with which I have always placed it in my collection.

Chelisoches tenebrator, Kirby, may perhaps require another genus, as the feet seem to have a somewhat distinct structure.

\section{Genus 5.-Proreus, * nov. gen.}

Statura mediocri; cum Chelisoche congruet; differt autem antennis gracilioribus, segmento 4 ovato, vel cylindrico, nec incrassato, nec clavato nec conico.

$$
\text { * Gr. } \pi \rho \omega \rho \varepsilon \dot{s}=\text { pilot. }
$$

TRANS. ENT. SOC. LOND. 1907.-PART I. (JUNE) 9 
I have erected this new genus, of which $P$. simulans, Stål, may be regarded as the type, for those somewhat smaller species, generally brown or reddish in colour, though sometimes black and variegated, which are closely allied structurally to $\mathrm{Ch}$. morio, and long regarded as congeneric with that species; they have, however, a different appearance, but I was long unable to find a satisfactory character common to all the species; in $P$. simulans, the antennæ are noticeably thin and slender, but $P$. ritsemæ approaches nearer to Ch. morio. The shape of the pronotum is that of typical Chelisoches, as also that of the feet.

The type is Forficula simulans, Stal, Eug. Resa. Ins., p. 302. (1858.)

\section{TABLE OF SPECIES.}

1. Forceps validus, deplanatus.

2. Forceps inermis (colore nigro, rufovariegato, pedibus annulatis) . 1. variopictus, Borm.

2.2. Forceps dentatus.

3. Pronotum sublatiusquam longius

3.3. Pronotum sublongius quam latius, postice quam antice paullo latius.

4. Unicolor fusco-testaceus . . .

4.4. Versicolores.

5. Elytra unicoloria testacea (statura parva ; caput nigrum). . . . . . . .

5.5. Elytra vittata.

6. Pronotum bicolor.

7. Colore nigro ; antennæ pedesque rufescentes .

7.7. Colore rufo; antennæ annulatæ . . . .

6.6. Pronotum unicolor flavum .

2. sobrius, Borm.

3. ritsemæ, Borm.

4. melanocephalus, Dohrn.

5. latior, Dohrn.

6. elegans, Borm.

7. ludekingi, Dohrn.

1.1. Forceps tenuis, haud vel vix deplanatus.

2. Elytra unicoloria fusca; forceps rectus, tantum apice ipso curvatus . . . . . . . . . 8. fuscipennis, Haan.

2.2. Elytra vittata.

3. Forceps arcuatus. 
4. Pronotum rufum, nigrovariegatum . . . . . . .

4.4. Pronotum unicolor flavum .

3.3. Forceps rectus, tantum apice ipso curvatus . . . . 9. simulans, Stål.

\section{Genus 6.-Solenosoma, nov. gen.}

Corpus gracile, cylindricum ; antennæ segmento 3 quam primum tertia parte breviori, elongato, tenui ; 4 ovato, cylindrico, quam tertium dimidio breviori; ceteris elongatis, cylindricis ; caput sat planum, postice timidum, margine, postico recto: pronotum capite subangustius, dimidio longius quam latius, postice dilitatum, margine antico recto, postico truncato, angulis rotundatis; lateribus rectis, reflexis: elytra brevia, apice truncata, carinula humerali brevissima ; angulo humerali haud rotundato ; angulo basali rotundata, scutellum parvum liberantia ; alæ nullæ: pedes sat graciles ; femora subincrassata, haud elongata; tibiæ breves, in dimidio apicali superne deplanatæ et subsulcatæ ; tarsorum segmento secundo sub tertium in lobum angustum producto: abdomen cylindricum, elongatum, parallelum, gracile, minute punctulatum, plicis lateralibus distinctis : segmentum ultimum dorsale magnum, quadratum, margine postico rugoso ; pygidium parvum ; forcipis bracchia basi remota, gracillima, valde elongata, subrecta, margine interno basi crenulata.

The unique species for which I have raised this genus was first ranged by de Bormans in Auchenomus, from which it differs in the form of the pronotum, and then in Chelisoches, from which it differs in the elongate and almost perfectly cylindrical body and the forceps, which recall in type those of Neolobophora. The pronotum has the form typical of Chelisoches and Proreus.

The type is Auchenomus birmanus, Borm., Ann. Mus. Civ. Gen. (2), vi, p. 436, fig. §ิ. (1888.) (Burmah.)

\section{Genus 7.-Enkrates,* nov. gen.}

Statura mediocri ; antennæ fortiores ; segmento 3 sat longo, quam $4+5$ subbreviori ; 4 et 5 subæquantibus, incrassatis, subclavatis; ceteris longioribus ; caput læve, tumidum, haud impressum, suturis obsoletis; pronotum caput latitudine æquans, paullo dilatatum, latius quam longius, transversum, margine postico rotundato; elytra

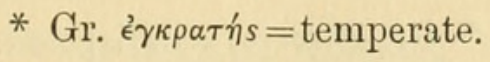




\section{Mr. Malcolm Burr's Preliminary Revision of the}

angusta, apice truncata, carinula humerali brevissima; alæ longæ ; pedes breves; tibiæ vix depressæ, haud vel vix sulcatæ ; abdomen subdilatatum; segmentum ultimum dorsale magnum, transversum, margine postico medio impresso, utrinque tuberculato; pygidium parvum; forceps of basi incrassatus, subtriquetris; margine interno dente acuto magno armatus, areuatus; $q$ subrectus, inermis.

In its variegated colour and the armature and shape of the forceps, as well as in the broad and transverse pronotum, this genus approaches more nearly to Forficula; it has the head of typical Forficula, while the tarsi are clearly referable to the group of the Chelisochidx.

The only known species is Enkrates flavipennis, Fabr., from West Africa, of which the synonymy is rather confused.

Forficula flavipennis, Fabr., Ent. Syst., ii, p. 5. (1793.)

Forficula flavipennis, Scudd., Proc. Bost. Soc. N. H., xviii, p. 314. (1876.)

Sphingolabis Alavipennis, Kirby, W. F., Cat. Orth. i, p. 46. (1904.)

Sphingolabis variegata, Kirby, W. F., Linn. Soc. Journ. Zool., xxiii, p. 326. (1891.) id. op. cit. xxv, p. 529, Pl. XX, fig. 9. (1896.)

Forficula variegata, Borm., Tierreich, Forf., p. 127. (1900.)

Chelisoches vittatus, Burr, Ann. Mag. N. H. (7), xi, p. 274 . (1903.)

Chelisoches limbatus, Borg. Arkiv. för Zool. Bd., i, p. 575, Pl. XXVI, fig. 7. (1904.)

\section{Genus 8.-Adiathetus, ${ }^{*}$ nov. gen.}

Statura mediocri vel magna; antennæ 20-segmentatæ, segmento 3 longo, sed quam $4+5$ unita breviori; 4 quam 3 dimidio breviori, clavato ; 5 clavato, 3 subæquanti : ceteris elongatis, subconicis: caput tumidum, suturis sat distinctis, margine postico recto; pronotum subquadratum, postice hand vel vix dilatatum, margine antico recto, postico subrotundato, lateribus rectis, angulis posticis rotundatis; prozona tumida, sutura mediana distincta, utrinque puncto impresso instructa; metazona plana, lata ; elytra carinula humerali brevi, lævia vel granulosa, læte metallico-nitentia; alæ longæ, eodem colore: pedes sat graciles; tibiis superne integris; abdomen validum, convexum, parallelum ; plicis lateralibus distinctis; segmentum ultimum dorsale of magnum, quadratum

* Gr. à $\delta$ เá $\theta \in \tau o s=$ indisposed. 
læve, tuberculatum ; $\uparrow$ magnum, subquadratum, integrum : pygidium of parvum ; $q$ parvum, vel longe productum; forcipis bracchia of brevia, incurva, robusta, valida, depressa, denticulata ; $q$ elongata, gracilia.

The species which I include in this genus was included by Verhoeff in his genus Chelisochella, but as that is characterised by the long keel of the elytra, a feature which is wanting in this species, they cannot be ranged in that genus. The German author appears to have been unfamiliar with the insects themselves, and assumed from the metallic colour and somewhat broad elytra that they fell in his genus.

The type and only known species is Chelisoches shelfordi, Burr, Ann. Mag. Ent. (7), vi, p. 96, Pl. IV, fig. 4. (1900.) (Sarawak.) (Ch.hercules, Burr, l.c. is the male.)

\section{Genus 9.-Hamaxas, ${ }^{*}$ nov. gen.}

Statura minore; colore nigro, rufo-variegato ; antennæ 16segmentatæ; segmento 3 sat brevi, subconico; $4+5$ tertium superantibus, ovatis, 5 quam 4 longiori; ceteris subconicis, elongatis ; caput læve, depressum, suturis vix perspicuis, margine postico truncato: pronotum quam caput æque latum, paullo longius quam latius, subovatum, margine antico lateribusque convexis, postico rotundato, postice haud dilatatum ; prozona vix tumida, sutura distincta ; elytra minute punctulata, apice truncata, lata, carinula humerali brevissima, valde pubescentia ; alæ similes : pedes breves, valde pubescentes ; tibiæ superne teretes, integres ; abdomen valde pubescens, sat depressum, parallelum, plicis lateralibus distinctis ; segmentum ultimum dorsale ô magnum, quadratum ; $q$ angustatum : pygidium of brevissimum, quadratum, transversum; $q$ vix perspicuum, subglobosum: forcipis bracchia of depressa, sat valida, vix incurva, brevia, valde pubescentia, intus dentata $; \mid+$ subcontigua, recta, brevia, inermia.

The species of the genus have always appeared quite unnaturally associated generically with Chelisoches morio; the brown and black uniform, the small size, very hairy body, all point to a different group; but the general characters of Chelisoches are present, except that the pronotum is shorter and broader, and more ovate, not dilated posteriorly, and also the tibiæ are smooth above, and not depressed nor sulcate.

* Gr. $\ddot{\alpha} \mu \alpha \xi \alpha s=$ coachman. 
The type is Chelisoches fex, Borm., Ann. Mus. Civ. Gen., xxxiv, p. $383 . \quad$ (1894.)

\section{TABLE OF SPECIES.}

1. Pronotum nigrum.

2. Antennæ segmentis 1-2 nigris, 3-7 flavis, 8-9 brunneis, 10-11 flavis, 12-15 fuscis, elytra fusco-brunnea 1. variicornis, Borm.

2.2. Antennæ nigræ, ante apicem pallidoannulatæ; elytra nigra . . . . 2. fex, Borm.

1.1. Pronotum flavidum.

2. Antennæ segmentis 1-13 nigris, 14-15 albis, apice fuscæ; elytra nigra . .

2.2. Antennæ segmentis 1-4 flavidis; 5-10 fuscis ; elytra fusco-brunnea 4. semiluteus, Borm.

Explanation of Plate IV.

[See Explanation facing the Plate.] 


\section{$2 \mathrm{BHL}$ Biodiversity Heritage Library}

Burr, Malcolm. 1907. "V. A preliminary revision of the Forficulidæ (sensu stricto) and of the Chelisochidæ, families of the Dermatoptera." Transactions of the Entomological Society of London 55, 91-134. https://doi.org/10.1111/j.1365-2311.1907.tb03066.x.

View This Item Online: https://www.biodiversitylibrary.org/item/48288

DOI: https://doi.org/10.1111/j.1365-2311.1907.tb03066.x

Permalink: https://www.biodiversitylibrary.org/partpdf/24632

\section{Holding Institution}

Smithsonian Libraries

\section{Sponsored by}

Smithsonian

\section{Copyright \& Reuse}

Copyright Status: Public domain. The BHL considers that this work is no longer under copyright protection.

This document was created from content at the Biodiversity Heritage Library, the world's largest open access digital library for biodiversity literature and archives. Visit BHL at https://www.biodiversitylibrary.org. 